\title{
ANALYSIS OF PRODUCT QUALITY, SALES PROMOTION, BRAND IMAGES, AND AFTER-SALES SERVICE TOWARDS SAMSUNG GADGET PURCHASE DECISIONS
}

\author{
Lina Safitriani, \\ Faculty of Economics and Business, Narotama University Surabaya \\ LinaSA2795@gmail.com \\ Agus Baktiono , \\ Faculty of Economics and Business, Narotama University Surabaya \\ agus.baktiono@narotama.ac.id \\ I Gedhe Arimbawa , \\ Faculty of Economics and Business, Narotama University Surabaya \\ gede.arimbawa@narotama.ac.id \\ Elok Damayanti \\ Faculty of Economics and Business, Narotama University Surabaya \\ elok.damayanti@narotama.ac.id
}

\begin{abstract}
This study aims to determine the effect of simultaneous and partial product quality, brand image, sales promotion and after-sales service on purchasing decisions of Samsung smartphones at the Discovery Mobile Store in Sidoarjo. This research used quantitative method. The population and sample based on the questionnaire distribution to consumers who visited the Discovery Ponsel Store Sidoarjo, and were taken as 135 respondents. Data collection techniques used interviews, observation and questionnaires. The data analysis used reliability test, validity test, classic assumption test and multiple linear analysis test. The simultaneous and partial results of product quality, brand image, sales promotion and aftersales service have a significant effect on the purchase decision of Samsung smartphones at the Discovery Ponsel Sidoarjo Store because of the significance of $<0.005$.
\end{abstract}

Keywords: Product Quality, Brand Image, Sales Promotion, and After-Sales Service, Purchasing Decision.

\section{INTRODUCTION}

The smartphone industry is getting denser with the presence of Chinese producers. This has a lot of impact on the growth of the business of old players, one of them is Samsung.

Samsung has been known as the largest smartphone manufacturer with the most market share in the world. The position seems to be slowly going down, at least as the analysis predicts. UD Discovery is engaged in retail cellphones, especially Samsung. The number of companies that sell similar products in Surabaya, makes competition even tighter, but the quality of products, promotions, brands and aftersales. Is one of the marketing tools used by companies to achieve their marketing goals in the target market.

\section{Research Objective}

Based on the formulation of the problem above, the objectives of the research to be carried out are: 
1. Analyze the effect of product quality, brand image, sales promotion and after-sales service simultaneously on Samsung smartphone purchasing decisions at Discovery Ponsel Sidoarjo Shop

2. Analyze the influence of product quality, brand image, sales promotion and after-sales service simultaneously on Samsung smartphone purchasing decisions at Discovery Ponsel Sidoarjo Shop

\section{Theoriticial Framework}

1. Product Quality

Product quality is quality which includes efforts to meet or exceed customer expectations that include products, services, people, processes, and the environment (Tjiptono, 2012).

2. Brand Image

Brand image is a set of consumer beliefs about a particular brand (Kotler and Armstrong (2001: 225) in (Hermansyur, H.., \& Aditi, 2017)

3. Sales promotion

Sales promotion is a form of direct persuasion through the use of various incentives that can be arranged to stimulate immediate product purchases and / or increase the amount of goods purchased by customers (Tjiptono (2008: 229) in (Mutia \& Roisah, 2016)

4. After Sales Service

After-sales services are consumer perceptions of after-sales services (Pariyanto and Lukmandono, 2017)

\section{Previous Research}

Hermansyur, H.., \& Aditi, 2017) entitled "The Influence of Product Quality, Brand Image, Price, and Promotion on the Purchase Decision of Honda Brand Cars in Medan City" The results of the study prove that there is a significant influence on product quality on car purchasing decisions the Honda brand in the city of Medan is $25 \%$. There is a significant influence on the brand image of the decision to purchase a Honda brand car in the city of Medan is $46.7 \%$. There is a significant effect on the price of purchasing decisions for Honda brand cars in the city of Medan is $29.7 \%$. There is a significant effect of promotion on the purchase decision of Honda brand cars in the city of Medan is $40.2 \%$

Parengkuan, Tumbel, \& Wenas, (2014) entitled "Analysis of the Effect of Brand Image and Celebrity Endorser on Purchasing Decision on Head And Shoulders Shampoo Products at 24 Mart Manado" The results of this study stated that Brand Image and Celebrity Endorsement had a simultaneous effect on consumer purchasing decisions. Partially Brand image does not have a significant effect on consumer purchasing decisions. Partially Celebrity Endorsment has a significant effect on consumer purchasing decisions.

Mutia \& Roisah, (2016) entitled "The Influence of Sales Promotion and Service Quality on the Purchase Decisions of Honda Motorcycles at CV. The Endless Blessing of Ujungberung Motorbikes "The results of the study prove that the variable sales promotion and service quality have a positive and significant effect on purchasing decisions partially and simultaneously have an influence of $87.7 \%$

Afiff Yudha Tri Pariyanto, Lukmandono (2017), entitled "Effect of product quality, product price, promotion and after-sales service on purchasing decisions of Honda motorcycles (research beat type) The results of the study prove that all independent variables (product quality, price, promotion and after-sales service) have a positive effect $t$ the purchase decision. The biggest positive influence on purchasing decisions of Honda Beat Mathic on Senior High School Albashtomi Students is on Product Quality variables with the test results of 4.822, then followed by price variables with a calculated value of 4.455 , then promotion variables with a value of 2.985 and lowest after-sales service variable with a calculated value of 2.367 .

Pratama \& Dwiarta, (2017) entitled "The Influence of Brand Trust and Product Quality on Purchasing Decisions of Honda Beat Motorcycle Product Consumers in Karangpilang SubDistrict, Surabaya City" The results of this study indicate that Brand and Product Quality Simultaneously and Partially have a significant effect on decisions purchase. Based on the 
data analysis concluded that there is a simultaneous influence between Brand Trust and Purchased Product Quality with an F value of 8,603 marks at 0,000. While the partial test shows that each variable has an effect on competency with the value of the Brand Trust is not equal to 2,950 marks 0,000 and Product Quality is 2,619 signs at 0,010 .

Amron, (2018) entitled "The Influence of Image Brands, Brand Trusts, Product Quality, and Price on the Consumer's Buying Decision of MPV Cars", the results of this study indicate that there are influences on Brand Image, Brand Trust, Product Quality, and Price towards consumer decisions in buying MPV cars.

Hatta et. al, (2018) entitled "Analysis of Product Innovation, Product Quality, Promotion, And Price, And Purchase Decisions", the results showed that respondents' perceptions of innovation and product quality, price, promotion, and the level of purchasing decisions were high; product innovation and promotion does not affect purchasing decisions. While product quality and prices influence purchasing decisions.

Brata at.al, 2017) entitled "The Influence Of Quality Products, Price, Promotion, And Location To Product Purchase Decision On Nitchi At PT. Jaya Swarasa Agung In Central Jakarta ", The results of the study show that product quality, price, promotion, and location influence purchasing decisions, both partially and simultaneously

Nangoy And Tumbuan, (2018) entitled "The Effect Of Advertising And Sales Promotion On Consumer Buying Decision Of Indovision Tv Cable Provider", The results of this study indicate that there is a significant influence between advertising and sales promotion about consumer purchasing decisions

Onigbinde Isaac Oladepo (Ph.D.) \& Odunlami Samuel Abimbola (M.Sc.), (2015) entitled "The Influence of Brand Image and Promotional Mix On Consumer Buying Decision-A Study of Beverage Consumers in Lagos State, Nigeria" , The findings reveal that brand image, advertising, sales promotion, and personal sales have a significant influence on consumers purchasing decisions

\section{Type of Research}

\section{METHODOLOGY}

This type of research is causal research (looking for a cause and effect by using a hypothesis), where the object of this research is a case study conducted on consumers who visit the Sidoarjo Discovery Mobile Shop.

This study will use a quantitative approach, according to (Prof. Dr. sugiyono, 2016) quantitative method is a scientific approach that views a reality that can be classified, concrete, observable, and measurable, the relationship of variables is causal where the research data is in the form of numbers and analysis use statistics. The independent variables in this study are Product Quality, Brand Image, Sales Promotion, After-Sales Service, Purchasing Decision. The purpose of this study is more towards the results of generalizations, explaining phenomena in a more measurable manner and various evidences to be found. Data collection to obtain results of discussion, analysis and conclusions that can be justified.

\section{Place and Time of Research}

This research was conducted at the Discovery Mobile Shop in Sidoarjo. The research was conducted from June 2019 - July 2019. 


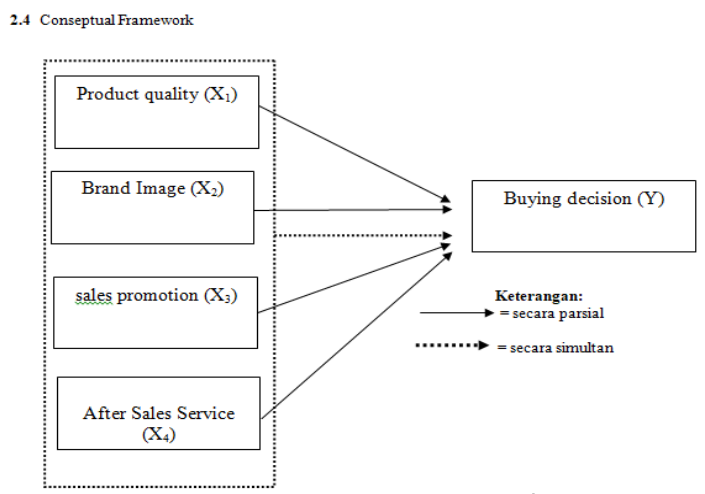

\section{Population and Sample}

Figure 1 : Conceptual Framework

The population in this study were consumers who visited the Discovery Ponsel Sidoarjo Shop, totaling 135 people. The sampling technique used is a non-probability sampling technique precisely purposive sampling. According to (Sugiyono, 2014) purposive sampling is a sampling technique of data sources with certain considerations. Based on these opinions, the research samples were consumers who visited the Sidoarjo Discovery Mobile Shop. which amounted to 135 people totaling 135 people.

\section{Data Collection Method}

The data sources used in this study use primary data and secondary data. Primary data are data obtained directly from the object of research. And secondary data, researchers get from data that has been processed by third parties, through books, libraries, libraries, and sources from the internet.

\section{Multiple Regression Analysis Model}

The data analysis technique used in this study is multiple regression analysis techniques. This analysis is intended to determine the effect of Product Quality (X1), Citra Merekt (X2), Sales Promotion (X3) and After-Sales Service on employee performance (Y):

$$
Y=a+b 1 X 1+b 2 X 2+b 3 X 3+b 4 X 4+e .
$$

\section{Reliability and Validity}

\section{RESULTS AND DISCUSSION}

Based on the research, the alpha cronbanch value is 0.881 , which means that it is above the acceptance limit of 0.6 . Therefore, the research instrument for the relationship between variables shows good consistency and acceptable data. Based on the research value of the correlation index for the relationship between the independent variables (Product Quality, Sales Promotion, Brand Image, After Sales Service) and the dependent variable (Purchasing Decision) below the significant level of $5 \%(0.05)$. Therefore, the data is considered valid. 


\section{Multiple Linier Regression}

Table 1. Multiple Linier Regression Result

Coefficients $^{\mathrm{a}}$

\begin{tabular}{|c|c|c|c|c|c|}
\hline \multirow[b]{2}{*}{ Model } & \multicolumn{2}{|c|}{$\begin{array}{l}\text { Unstandardized } \\
\text { Coefficients }\end{array}$} & \multirow{2}{*}{$\begin{array}{c}\text { Standardized } \\
\text { Coefficients } \\
\text { Beta }\end{array}$} & \multirow[b]{2}{*}{$\mathrm{T}$} & \multirow[b]{2}{*}{ Sig. } \\
\hline & $\mathrm{B}$ & Std. Error & & & \\
\hline 1 (Constant) & 3.925 & 1.763 & & 2.226 & .028 \\
\hline TOTAL_KP & .093 & .047 & .141 & 1.992 & .049 \\
\hline TOTAL_PP & .120 & .053 & .139 & 2.263 & .025 \\
\hline TOTAL_CM & .309 & .088 & .246 & 3.504 & .001 \\
\hline TOTAL_LPJ & .662 & .115 & .460 & 5.768 & .000 \\
\hline
\end{tabular}

a. Dependent Variable: TOTAL_KE_P

Source: SPSS Output, 2019

Regression equation models that can be written from these results in the form of standard form regression equations are as follows:

1. Constant

$$
\mathrm{Y}=3,925+0,93 \cdot \mathrm{X} 1+0,120 \cdot \mathrm{X} 2+0,309 \cdot \mathrm{X} 3+0,662 \cdot \mathrm{X} 4+\mathrm{e}
$$

Obtained $Y$ constant value of 3.925 means Consumer Purchasing Interest $(Y)$ of 4.419 units if it is assumed that Product Quality (X1), Sales Promotion (X2), Brand Image (X3), After Sales Service (X4), Consumer Purchase Decision ( $Y$ ) is 0 means that if the value of the independent variable 0 then the dependent or dependent variable will be 3,925.

2. Product Quality Coefficient Value (X1)

The Product Quality Coefficient (X1) is 0.093 , if the Discovery Ponsel Sidoarjo Shop improves Product Quality (X1) then it will increase the Consumer Purchase Decision (Y) by 0.093 units. Assuming the value of Sales Promotion (X2) and Location (X3) equals zero.

3. Sales Promotion Coefficient Value (X2)

The coefficient of Sales Promotion (X2) is 0.120 , if the Discovery Ponsel Sidoarjo Shop increases Sales Promotion (X2) then it will increase the Consumer Purchase Decision ( $Y$ ) by 0.120 units. Assuming the value of Product Quality (X1) and Brand Image (X3) is zero

4. Brand Image Coefficient Value (X3)

The Brand Image coefficient value (X3) is 0.309 , if the Discovery Ponsel Sidoarjo Shop increases the Brand Image (X3) of food, it will increase the Consumer Purchase Decision (Y) by 0.309 units. Assuming the value of Product Quality (X1) and Sales Promotion (X2) equals zero

5. Coefficient of After Sales Service (X4)

The coefficient of After-Sales Service (X4) is 0.662, if the Discovery Ponsel Sidoarjo Shop increases After-Sales Service ( $X 4)$ food will increase Consumer Purchase Decision $(Y)$ by 0.662 units. Assuming the value of Product Quality (X1) and Sales Promotion (X2) equals zero

\section{Result of R Square}

The value of $R$ Square is 0.705 , which means that all independent variables: Product Quality, Sales Promotion, Brand Image, After-Sales Service, and Purchase Decisions.

\section{Multicollinearity Test}


Table 2. Multicollinearity Test

\begin{tabular}{|c|c|c|c|}
\hline & Collin & rity & \\
\hline Variabel & Stat & & Information \\
\hline vallavel & $\begin{array}{c}\text { Toleranc } \\
e \\
\end{array}$ & VIF & IItration \\
\hline Product Quality $\left(\mathrm{X}_{1}\right)$ & 0,707 & 1,414 & $\begin{array}{c}\text { Free } \\
\text { multicollinearity }\end{array}$ \\
\hline Sales Promotion $\left(\mathrm{X}_{2}\right)$ & 0,940 & 1,064 & Free \\
\hline Brand Image $\left(X_{3}\right)$ & 0,718 & 1,393 & $\begin{array}{c}\text { Free } \\
\text { multicollinearity }\end{array}$ \\
\hline $\begin{array}{l}\text { After Sales Service } \\
\left(\mathrm{X}_{4}\right)\end{array}$ & 0,557 & 1,796 & $\begin{array}{c}\text { Free } \\
\text { multicollinearity }\end{array}$ \\
\hline
\end{tabular}

Berdasarkan Tabel 2. dapat dilihat bahwa model regresi tidak mengalami gangguan multikolinearitas. Hal ini tampak pada nilai tolerance masing-masing variabel bebas yang lebih besar dari 0,1. Hasil penghitungan VIF juga menunjukan bahwa nilai VIF masing-masing variabel independen kurang dari 10. Jadi dapat disimpulkan bahwa tidak ada multikolinearitas antar variabel bebas dalam model regresi

\section{Heteroscedasticity Test}

Scatterplot

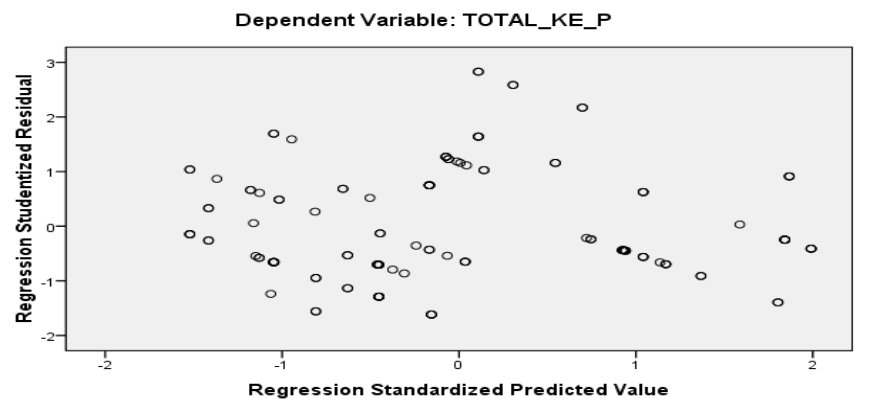

Figure 2: Heteroscedasticity

Based on the graph above it can be seen that the distribution of data is irregular and does not form a specific pattern, and is spread over and below the number 0 on the $Y$ axis, so it can be concluded that in this regression model there is no problem of heteroscedasticity.

\section{Normality test}

Normal P-P Plot of Regression Standardized Residual

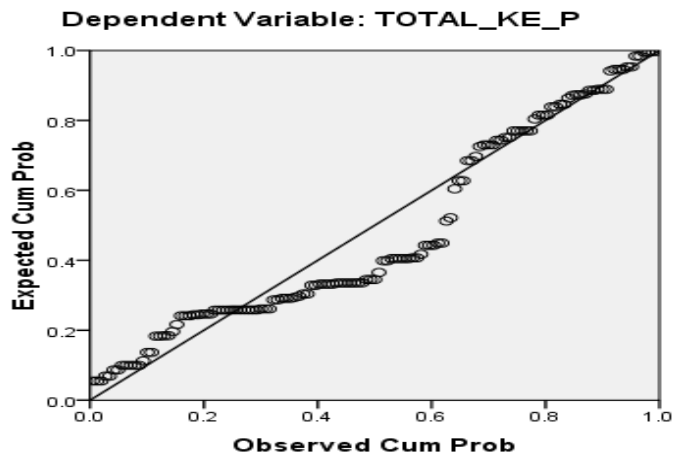

Figure 3: Results of Calculation of Normality

Based on the graph above shows that all existing data are normally distributed, because all data spreads form a diagonal straight line, then the data meets normal assumptions or follows the normality line. 


\section{Hypothesis Testing \\ F-Test}

The F-test is used to determine all effects of all independent variables on the dependent variable. This test is done by comparing the Fcount value with Ftable value at $\alpha=0.05$..

Table 4: Test Results - F

\begin{tabular}{cccccc}
\multicolumn{5}{c}{ ANOVA $^{\mathbf{b}}$} \\
\hline Model & $\begin{array}{c}\text { Sum of } \\
\text { Squares }\end{array}$ & df & $\begin{array}{c}\text { Mean } \\
\text { Square }\end{array}$ & F & Sig. \\
\hline $1 \begin{array}{c}\text { Regres } \\
\text { sion } \\
\text { Residua } \\
\text { I }\end{array}$ & 450.415 & 4 & 112.604 & $\begin{array}{r}38.08 \\
1\end{array}$ & $.000^{\mathrm{a}}$ \\
Total & 384.400 & 130 & 2.957 & & \\
\hline Redictors: (Constant), TOTAL_LPJ, TOTAL_PP, TOTAL_CM,
\end{tabular}

a. Predictors: (Constant), TOTAL_LPJ, TOTAL_PP, TOTAL_CM, TOTAL_KP

b. Dependent Variable: TOTAL_KE_P

The F-test is used to determine all effects of all independent variables on the dependent variable. This test is done by comparing the Fcount value with Ftable value at $\alpha=0.05$. Overall Influence of Product Quality, Sales Promotion, Brand Image, Full Service for Purchasing Decisions with a significance of $0,000>0.05$.

\section{T-Test}

Table 5 : T-Test Result

\section{Coefficients $^{a}$}

\begin{tabular}{|c|c|c|c|c|c|c|}
\hline & \multirow[b]{2}{*}{ Model } & \multicolumn{2}{|c|}{$\begin{array}{l}\text { Unstandardized } \\
\text { Coefficients }\end{array}$} & \multirow{2}{*}{$\begin{array}{c}\text { Standardized } \\
\text { Coefficients } \\
\text { Beta }\end{array}$} & \multirow[b]{2}{*}{$\mathrm{t}$} & \multirow[b]{2}{*}{ Sig. } \\
\hline & & B & Std. Error & & & \\
\hline \multirow[t]{5}{*}{1} & (Constant) & 3.925 & 1.763 & & 2.226 & .028 \\
\hline & $\underset{P}{\text { TOTAL_K }}$ & .093 & .047 & .141 & 1.992 & .049 \\
\hline & $\underset{P}{\text { TOTAL_P }}$ & .120 & .053 & .139 & 2.263 & .025 \\
\hline & $\begin{array}{c}\text { TOTAL_C } \\
\mathrm{M}\end{array}$ & .309 & .088 & .246 & 3.504 & .001 \\
\hline & $\begin{array}{l}\text { TOTAL_L } \\
\text { PJ }\end{array}$ & .662 & .115 & .460 & 5.768 & .000 \\
\hline
\end{tabular}

a. Dependent Variable: TOTAL_KE_P

1. Table 5 shows that thitung Product Quality (X1) is 1.992 with sig 0.001 smaller than 0.05 so $\mathrm{Ho}$ is rejected and $\mathrm{Ha}$ is accepted. Therefore Product Quality (X1) has a significant influence on Purchasing Decisions

2. Table 5 shows that thitung Sales Promotion (X2) is 2,263 with sig 0,000 smaller than 0.05 so $\mathrm{HO}$ is rejected and $\mathrm{Ha}$ is accepted. Therefore Sales Promotion

3. Table 5 shows that the Brand Image tcount (X3) is 3.504 with sig 0,000 smaller than 0.05 , $\mathrm{HO}$ is rejected and $\mathrm{Ha}$ is accepted. Therefore Brand Image (X3) has a significant influence on Purchasing Decisions

Product Quality for Purchasing Decisions 
The first hypothesis proposed states that Product Quality is partially towards the Purchase Decision of the Discovery Mobile Store in Sidoarjo, this has been proven by the value of the t test results 1.992 .

Sales Promotion for Purchasing Decisions

The second hypothesis proposed states that the sales promotion is partially towards the Purchase Decision of the Discovery Mobile Store in Sidoarjo, this has been proven by the results of the t test value of 2.263.

Brand Image of Purchasing Decisions

The third hypothesis proposed states that the brand image is partially towards the Purchase Decision of the Discovery Mobile Sidoarjo shop, this has been proven by the results of the t test value 3,508.

After-sales service for purchasing decisions

The fourth hypothesis proposed states that after-sales service is partial to the Purchase Decision of the Discovery Mobile Sidoarjo shop, this has been proven by the results of the $t$ test value 5,768

Product Quality, Sales Promotion, Brand Image, and After-Sales Service Influence the Purchase Decision of the Shop Discovery Mobile Sidoarjo

The fifth hypothesis proposed states that Product Quality, Sales Promotion, Brand Image, and After-Sales Service have a significant simultaneous effect on the Purchase Decision of the Discovery Mobile Sidoarjo Shop with the results of the F test value 38,081 .

\section{CONCLUSION}

1. Variable Product Quality (X1), Brand Image (X2), Sales Promotion (X3), After-Sales Service (X4), simultaneously have a significant effect on Purchasing Decisions (Y).

2. Product Quality (X1), Brand Image (X2), Sales Promotion (X3) and After-Sales Service (X4) variables partially have a significant effect on purchasing decisions (Y).

\section{REFERENCES}

Amron. (2018). The Influence of Brand Image, Brand Trust, Product Quality, and Price on the Consumer's Buying Decision of MPV Cars. Jurnal Ekono Insentif Kopwil4, 10(2), 1017.

Brata at.al. (2017). The Influence of Quality Products, Price, Promotion, and Location to Product Purchase Decision on Nitchi At PT. Jaya Swarasa Agung in Central Jakarta. Saudi Journal of Business and Management Studies ISSN 2415-6671.

Hatta et. al. (2018). Analysis Of Product Innovation, Product Quality, Promotion, And Price, And Purchase Decisions. South East Asia Journal of Contemporary Business, Economics and Law, Vol. 16, I.

Hermansyur, H. ., \& Aditi, B. (2017). Pengaruh Kualitas Produk, Citra Merek, Harga dan Kualitas Produk Terhadap Keputusan Pembelian Mobil Merek Honda Di Kota Medan. Konsep Bisnis Dan Manajemen, 3(1), 32-4.

Mutia, E. R., \& Roisah, R. (2016). Pengaruh Promosi Penjualan Dan Kualitas Pelayanan Terhadap Keputusan Pembelian Sepeda Motor Honda Pada CV. Berkat Abadi Motor Ujungberung. Jurnal Ekono Insentif Kopwil 4, Volume 10 No. 2. ISSN: 1907 - 0640.

Nangoy Dan Tumbuan. (2018). The Effect Of Advertising And Sales PromotionOnConsumer Buying Decision Of Indovision Tv Cable Provider. Jurnal EMBA, Vol.6 No.3.

Onigbinde Isaac Oladepo (Ph.D.) \& Odunlami Samuel Abimbola (M.Sc.). (2015). The Influence Of Brand Image And Promotional Mix On Consumer Buying Decision- A Study Of Beverage Consumers In Lagos State, Nigeria. British Journal of Marketing Studies., Vol.3, No.

Parengkuan, Tumbel, \& Wenas. (2014). Analisis Pengaruh Brand Image Dan Celebrity Endorsment Terhadap Keputusan Pembelian Produk Shampo Head and Shoulders Di 24 Mart Manado. Jurnal EMBA, 2, 1792-1802. 
Pratama, F. A., \& Dwiarta, I. M. B. (2017). PENGARUH BRAND TRUST DAN KUALITAS PRODUK TERHADAP KEPUTUSAN PEMBELIAN KONSUMEN PRODUK SEPEDA MOTOR HONDA BEAT DI KECAMATAN KARANGPILANG, KOTA SURABAYA. Majalah Ekonomi, XXII(1).

Pratiwi, D. I. (2010). "Analisis Pengaruh Harapan Pelanggan, Kualitas Produk, dan Kepuasan Pelanggan Terhadap Loyalitas Pelanggan Internet Flash Unlimited di Semarang. Retrieved from https://core.ac.uk/download/files/379/11722037.pdf

Prof. Dr sugiyono. (2016). MetodePenelitian Kuantitatif, Kualitatif dan R\&D. Bandung: PT.Alfabet.

Sugiyono. (2014). Metode Penelitian Bisnis. Bandung: Alfabeta. 